\title{
3D PRINTING PHARMACEUTICAL FORMULATION OF DRUGS IN PERSONALIZED THERAPY
}

\author{
DOINA DRĂGĂNESCU ${ }^{1}$, DUMITRU LUPULIASA ${ }^{2}$, GEORGE TRAIAN ALEXANDRU \\ BURCEA DRAGOMIROIU ${ }^{3}$, ADRIAN COSMIN ROȘCA ${ }^{4}$, LUCIAN HÎNCU ${ }^{5 *}$, DANIELA \\ CIOACĂ $\breve{D}^{5}$
}

1 "Carol Davila" University of Medicine and Pharmacy Bucharest, Faculty of Pharmacy, Department of Pharmaceutical Physics and Informatics, 6 Traian Vuia Street, 020956, Bucharest, Romania

2 "Carol Davila" University of Medicine and Pharmacy Bucharest, Faculty of Pharmacy, Department of Pharmaceutical Technology and Biopharmaceutics, 6 Traian Vuia Street, 020956, Bucharest, Romania

3 “Carol Davila" University of Medicine and Pharmacy Bucharest, Faculty of Pharmacy, Department of Drug Control, 6 Traian Vuia Street, 020956, Bucharest, Romania

4 “Ovidius” University, Faculty of Pharmacy, Department of Drug Control, 6 Văpitan Av. Al. Șerbănescu Street, Constanța, Romania

5 "Carol Davila" University of Medicine and Pharmacy Bucharest, Faculty of Pharmacy, Department of Drug Industry and Pharmaceutical Biotechnologies, 6 Traian Vuia Street, 020956, Bucharest, Romania

*corresponding author: lucianhincu@gmail.com

Manuscript received: May 2018

\begin{abstract}
3D printing offers the key for manufacturing new pharmaceutical forms and devices with complex structures and geometry that meet individual needs of patients, improving compliance, accessibility and affordability of medicines. Also, due to 3D printing technologies, on demand fabrication of pharmaceutical products in critical situations may be an easy task in the future. In this review we focused on the main 3D printing technologies, 3D printers and 3D software platforms widely used at present. Also, we discuss the most important achievements that have been obtained lately using $3 \mathrm{D}$ printing in the pharmaceutical field.
\end{abstract}

\section{Rezumat}

Metodele de fabricare aditivă 3D reprezintă o tehnologie cu rol esențial în obținerea unor forme și dispozitive farmaceutice noi, cu structuri şi geometrii complexe, care corespund unor cerințe individualizate ale pacienților, ceea ce are ca efect creșterea complianței, accesibilității şi afordabilității medicamentelor. Tehnologiile de printare 3D oferă, de asemenea, perspectivele producerii rapide și eficiente a unor produse farmaceutice în situații critice. Articolul descrie principalele tehnologii de imprimare 3D, imprimantele 3D și platformele software care sunt disponibile în prezent, precum și cele mai importante realizări ale tehnogiei de imprimare 3D în domeniul farmaceutic.

Keywords: additive manufacturing, 3D printing, pharmaceutical

\section{Introduction}

$3 \mathrm{D}$ printing technology is different from traditional materials processing procedures. Sometimes considered a synonym for additive manufacturing, solid freeform fabrication, layered manufacturing or rapid prototyping $[1,2], 3 \mathrm{D}$ printing allows creation of three-dimensional objects by layer-by-layer deposition of printing materials [3]. This method has remarkable attributes like accuracy, repeatability and reliability [4].

3D printing uses Computer-Aided Design/ComputerAided Manufacturing (CAD/CAM) applications to design and control fabrication processes. CAD/CAM systems are composed by: a scanner that translates geometric features of a 3D object in digital data; a software that process digital data received from the scanner and controls; a device that manufacture desired object using a specific technology [5].
$3 \mathrm{D}$ printing has a great potential and applications in many fields, including medicine, electronics, aerospace, engineering and architecture. Various materials are used for $3 \mathrm{D}$ printing like sand, metals, ceramics and polymers [6].

The first commercial 3D printing technology, stereolitography, was invented in 1986 by Charles Hull, the co-founder and chief technology officer of 3D systems. In 1994 he received the Jacquard Award from the Numerical Controls Society. [7] In time, different methods for $3 \mathrm{D}$ printing have been developed like Inkjet-Based 3D printing, continuous inkjet printing (drop-on-demand), nozzlebased 3D printing technologies (fused deposition modelling, pressure-assisted micro syringes technology) and laser-based writing methods (stereolithography, laser-induced forward transfer) $[8,9,10]$. 
3D printing methods $[8,9,10,11,12,13]$

\begin{tabular}{|c|c|c|c|}
\hline Type & & type & Basic Principle \\
\hline \multirow{3}{*}{$\begin{array}{l}\text { Inkjet - based } \\
\text { printing } \\
\text { systems }\end{array}$} & \multicolumn{2}{|c|}{$\begin{array}{l}\text { Continuous inkjet printing } \\
\text { (CIJ) }\end{array}$} & $\begin{array}{c}\text { Continuous column of droplets are generated and deposited to } \\
\text { selected positions on a target substrate. }\end{array}$ \\
\hline & \multirow{2}{*}{$\begin{array}{l}\text { Drop-on- } \\
\text { demand } \\
\text { (DOD) }\end{array}$} & Thermal DOD & $\begin{array}{l}\text { The pressure needed for ejection of the volatile printing material is } \\
\text { performed by a heating device. }\end{array}$ \\
\hline & & $\begin{array}{l}\text { Piezoelectric } \\
\text { technology }\end{array}$ & $\begin{array}{l}\text { The system contains a piezoelectric system that induce a rapid } \\
\text { deformation of the fluid printing ink, thus generating the pressure } \\
\text { required for ejection of the droplets. }\end{array}$ \\
\hline \multirow{2}{*}{$\begin{array}{l}\text { Nozzle -based } \\
\text { deposition } \\
\text { systems }\end{array}$} & \multicolumn{2}{|c|}{$\begin{array}{l}\text { Fused deposition modelling } \\
\qquad \text { (FDM) }\end{array}$} & $\begin{array}{l}\text { Is based on heating and extrusion of a semi-liquid thermoplastic ink } \\
\text { that is sequentially settled to obtain a 3D object using a removable } \\
\text { scaffold. }\end{array}$ \\
\hline & \multicolumn{2}{|c|}{$\begin{array}{l}\text { PAM (pressure-assisted micro } \\
\text { syringes) technology }\end{array}$} & $\begin{array}{l}\text { The viscous, semi-liquid ink is deposited layer by layer, according to } \\
\text { a pre-designed 3D form, using a microsyringe moved by pressure } \\
\text { generated by an air piston. }\end{array}$ \\
\hline \multirow{2}{*}{$\begin{array}{c}\text { Laser-based } \\
\text { writing system }\end{array}$} & \multicolumn{2}{|c|}{ Stereolithography (SLA) } & $\begin{array}{c}\text { UV laser transfers the energy to a photopolymerizable liquid resin. } \\
\text { The 3D object is build layer by layer from the photochemical } \\
\text { solidified resin. }\end{array}$ \\
\hline & \multicolumn{2}{|c|}{$\begin{array}{l}\text { Laser-induced forward transfer } \\
\text { (LIFT) }\end{array}$} & $\begin{array}{l}\text { The energy of a high-powered laser pulse deposit the printing material } \\
\text { on a receptor substrate. The system has a sacrificial layer (usually a } \\
\text { metallic film volatilized under the laser pulse) and a transfer layer. }\end{array}$ \\
\hline
\end{tabular}

Table II

3D printing technologies classification [14]

\begin{tabular}{|c|c|}
\hline \multirow{4}{*}{ WD printing technologies } \\
\hline \multirow{4}{*}{ Working principles } & Binder jetting \\
\cline { 2 - 2 } & Material extrusion \\
\cline { 2 - 2 } & Directed energy deposition \\
\cline { 2 - 2 } & Powder based fusion \\
\cline { 2 - 2 } & Material jetting \\
\cline { 2 - 2 } & Vat photopolymerization \\
\hline \multirow{4}{*}{ Starting material states } & Sheet lamination \\
\cline { 2 - 2 } & Pluid material technologies \\
\cline { 2 - 2 } & Powder material technologies \\
\hline \multirow{4}{*}{ Energy sources } & Solid material technologies \\
\cline { 2 - 2 } & Inkjet-based printing \\
\cline { 2 - 2 } & Force (extrusion)-based printing \\
\cline { 2 - 2 } & Ultrasonic-based printing \\
\cline { 2 - 2 } & Electron beam-based printing \\
\cline { 2 - 2 } & UV-based printing \\
\hline \multirow{2}{*}{ Biological functions } & Printing without living cells \\
\cline { 2 - 2 } & Printing with living cells (3D bioprinting) \\
\hline
\end{tabular}

Another 3D printing method is free-form spatial 3$\mathrm{D}$ printing using part levitation that utilise acoustic or magnetic levitation of the printing material into space to form 3D objects. The method allows modification of the printed object by multiple print heads located in different positions. The 3D object can be moved and rotated to any angle without the need of a support structure [15].

The concept of 4D printing was developed by Skylar Tibbits from the Massachusetts Institute of Technology. He and his collaborators combined plastic filaments with a layer built of a "smart" material that is capable to undergo an auto contruction process in water [16]. In 4D printing, objects obtained by $3 \mathrm{D}$ printing are capable to self- transform into programmable, geometrically modified structures as a result to an extern stimulus (heat, $\mathrm{pH}$, light etc.). 4D printing uses "smart materials" like electroactive polymers, shape memory alloys, shape memory polymers etc.

\section{Software platforms for image processing in 3D printing.}

Osirix ${ }^{\circledR}$ MD is a medical images viewer widely used by healthcare professionals from the entire world. The software is dedicated to post process $2 \mathrm{D}$ and $3 \mathrm{D}$ images, for $3 \mathrm{D}$ and $4 \mathrm{D}$ navigation and supports 64-bit computing. It is certified and validated for clinical use in medicine (FDA, CE, ANVISA) [17]. 
3D Slicer was developed by National Institutes of Health and other collaborators as a free, open source software for medical image informatics, image processing and three-dimensional visualization. It is used for analysis (including registration and interactive segmentation) and visualization (including volume rendering) of medical images and for research in image guided therapy [18].

Meshmixer version 3.2 by Autodesk Inc. is a free software that can analyse and fix the printing model, thus correcting errors or irregularities and saving time and efforts [19].

Mimic is another software platform for 3D scanning image capture, 3D design and reverse engineering, 3D inspections and analysis, 3D printable models rapid prototyping, parametric CAD modelling and NURB modelling. It can be successfully used in reverse engineering, rapid prototyping, inspection (quality control, first article and production line measurement, geometric dimensioning and tolerance, animation (face and body scanning, data acquisition for 3D character creation, 3D worlds from physical scale models), surgery, dentistry, archaeology, architecture etc [20].

\section{D printers}

3D NovoGen $M M X^{\circledR}$ Printer (San Diego Organovo) is dedicated to create high-resolution representations of human cancerous networks. Cancerous cells derived from human donors or tumour cell banks are grown and replicated in the lab and further used in a $3 \mathrm{D}$ printing process. Subsequently, the cells will form a viable tissue that can be studied and tested using different drugs [21, 22].

Aether $^{\circledR} 1$ printer (Aether Inc.) can create 3D objects formed by maximum 24 materials (viscous pastes, gels, ceramics, filaments, oils, liquids, resins etc.), in one printing process. The modular system contains 8 syringes, 2 hot-ends and 10 extruder fabrication systems. Optional attachments with different functions are available [23].

BioFactory (RegenHU) prints organotypic tissues with in vivo like morphology. The printing process can be performed in physiological conditions. The system utilizes multiple technologies and contains a laser unit for photopolymerisation and biomolecules immobilization. Tissue modelling is easy and rapid. BioCAD software can design models with complex structures without a prior 3D archetype or an image that contain medical informations [24].

3D Discovery Bench Top (RegenHU) is intended for research and development. It creates threedimensional organomimetic models with composite structures for tissue engineering. The 3D Discovery BioSafety is a derivate of 3D Discovery Bench Top equipped with a class II biosafety cabinet [24].

Form 2 printer is dedicated to high-resolution 3D printing in digital dentistry. The system contains an integrated resin system in order to automatically fill in the tank printer during printing process and a 250 $\mathrm{mW}$ precision laser for high resolution. 3D Models are created with PreForm Software 2.12.3 [25].

3D Printer Families, Desktop, Prefactory, CDLM Printer, 3SP, VIRIDS3D, SLCOM, 3D-BIOPLOTTER, developed by Envision TEC use revolutionary DLP (digital light processing) technology. 3D-Bioplotter (starter, developer and manufacturer) Series print tissue, organs or other anatomical structures from biomaterials that solidify as a consequence of physical or chemical processes (hydrogels, melted polymers, ceramics, metals). The system uses air or mechanical pressure applied to a syringe, in highly accurate processes with $\mathrm{X}-\mathrm{Y}$ repeatability down to $1 \mu \mathrm{m}$. Printers can be used in sterile biosafety cabinets at standards required for clinical trials. Mechanic properties and cellular adhesion can be easily controlled in printing processes for tissue engineering [26].

Table III

Bioprinters [27]

\begin{tabular}{|c|c|c|c|c|}
\hline Printer & Company & Technology & $\begin{array}{l}\text { Materials for } \\
\text { printing }\end{array}$ & Price \\
\hline $\begin{array}{c}\text { 3D Bioplotter Manufacturer } \\
\text { Series + Developer Series }\end{array}$ & EnvisionTEC & Syringe extrusion & $\begin{array}{c}\text { Hydrogels } \\
\text { Silicon } \\
\text { Hydroxyapatite } \\
\text { Titan } \\
\text { Chitosan }\end{array}$ & $\begin{array}{c}\text { over \$ } \\
200,000\end{array}$ \\
\hline NovoGenMMX & Organovo & Syringe extrusion & Hydrogels & \\
\hline 3DDiscovery + Biofactory & RegenHU & Syringe extrusion & $\begin{array}{c}\text { Bioinks } \\
\text { Osteoinks }\end{array}$ & $\begin{array}{c}\$ 100,000- \\
200,000\end{array}$ \\
\hline BioBot1 & BioBots & $\begin{array}{l}\text { Syringe extrusion } \\
\text { Blue light technology }\end{array}$ & $\begin{array}{c}\text { Agarose } \\
\text { Collagen } \\
\text { Alginate } \\
\text { PEG }\end{array}$ & $\$ 10,000$ \\
\hline Inkredible & CELLINK & Syringe extrusion & $\begin{array}{c}\text { CELLINK } \\
\text { CELLINK A } \\
\text { Others }\end{array}$ & $\begin{array}{c}€ 5,000- \\
9,000\end{array}$ \\
\hline
\end{tabular}


FARMACIA, 2019, Vol. 67, 1

\begin{tabular}{|c|c|c|c|c|}
\hline Printer & Company & Technology & $\begin{array}{c}\text { Materials for } \\
\text { printing }\end{array}$ & Price \\
\hline Revolution & Ourobotics & Syringe extrusion & $\begin{array}{c}\text { Collagen } \\
\text { Alginate } \\
\text { Others } \\
\end{array}$ & $€ 12,500$ \\
\hline BioAssemblyBot & $\begin{array}{l}\text { Advanced } \\
\text { Solutions' }\end{array}$ & Syringe extrusion 6 axes & Different materials & $\$ 159,999$ \\
\hline Bioscaffolder 2.1 & GeSim & $\begin{array}{c}\text { Syringe extrusion } \\
\text { Piezoelectric pipetting }\end{array}$ & $\begin{array}{c}\text { Polymers } \\
\text { Pastes with high } \\
\text { viscosity } \\
\text { Alginate } \\
\text { Calcium phosphate } \\
\text { Silicon } \\
\text { Solutions with } \\
\text { proteins or cells } \\
\end{array}$ & $\$ 180,000$ \\
\hline Alpha \& Omega & $\begin{array}{l}\text { 3Dynamic } \\
\text { Systems }\end{array}$ & Syringe extrusion & $\begin{array}{c}\text { Natural polymers } \\
\text { Synthetic polymers } \\
\text { Calcium phosphate } \\
\text { Hydrogels }\end{array}$ & $£ 12-18,000$ \\
\hline
\end{tabular}

Currency: $\$$ - USD, $€$ - EUR, $£$ - GBP

\section{Top companies on the 3D printing market in healthcare field}

Among the leading companies that offer innovative products and services for $3 \mathrm{D}$ printing we can list Stryker (U.S.), Zimmer Biomet (U.S.), Boston Scientific Corporation (U.S.), Smith \& Nephew (U.K.), Biotronik (Germany), Tornier N.V. (The Netherlands), B.Braun (Germany), Science for Biomaterials (France), Kasios (France), Mediplus (UK).

Biotronik is a privately held company that offers medical technology and services for people with cardiac and circulatory diseases (pacemakers, stents, implantable defibrillators) in more than 100 countries [28].

Stryker, a leader in medical technology, provide a wide array of products and services in Orthopedics. It was founded as a hospital bed manufacturer in 1941. In the present, the company has three departments: Orthopedics, MedSurg (medical and surgical devices), Neurotechnology and Spine and delivers its devices in more than 100 countries. Some of Stryker's progressive innovations include robotics and 3D printing [29, 30]. In 2013, Stryker gained Mako system, that can be used in kneereplacement surgery, being able to create $3 \mathrm{D}$ models for fitting of the implant prior to the operation and to assist the physician during surgery. In 2017, Stryker launched its Mako Robotic-Arm Assisted Total Knee system made by Mako technology with Stryker's Triathlon Implant system. Stryker have been developed its own 3D printing process called AMagine (the "AM" "Additive Manufacturing"). The company is focused on 3D printed metallic devices (titanium). The company received FDA approval in 2016 for Tritanium PL (Posterior Lumbar) Cage, a 3D printed spinal implant that mimics the natural structure of bones [30, 31].

Biomet Orthopedics is oriented to design and manufacture orthopaedic implants. The company developed Signature technology. In 2012, Biomet Orthopedics demonstrated how the Signature technology function in real time surgery processes. This technology utilizes MRI imaging to offer 3D data about patient's anatomy in order to increase effectiveness of the procedures and to simplify partial knee arthroplasty interventions [32, 33].

Zimmer Biomet is another top company oriented to design foot and ankle joint fusion systems with 3D printing and OsseoTi porous metal technology. In 2016 the company announced FDA Clearance for Unite 3D Bridge Fixation System foot and ankle joint fusion system that has a structure that resemble the one of the cancellous bone and contains an osteoconductive material for embodiment of biological factors [34].

Smith \& Nephew is one of the best provider of joint replacement systems for knees, hips and shoulders. On 1 March 2016 the company launched REDAPT Revision Acetabular Fully Porous Cup with CONCELOC Technology. The product applicability is intended for revision cases with injuried bone that generate complications in implantation procedures. The porous implant is produced by a 3D manufacturing process and mimics the structure of the cancellous bone [35]. The company developed the Syncera program in order to lower hip and knee products prices by $40 \%$ to $50 \%$ for the market of $5 \%$ to $10 \%$ of U.S. hospitals [36].

St. Jude Medical, Inc. (US) announced on October 2013 the FDA approval for Ilumien Optis PCI optimization system, an innovative technology produced to support physicians with an all- 
FARMACIA, 2019, Vol. 67, 1

inclusive disease evaluation tool for people that suffer of coronary artery disease (CAD). The platform assists medical specialists in order to manage the disease in optimal conditions. The OCT imaging technology provides $3 \mathrm{D}$ reconstruction of the patient's vessel in real-time, making effortless for doctors the visualization of the treated area [37]. BioBots was founded as a 3D bioprinting start-up. The first product is BiotBots 1 that can print living tissues or non living scaffolds at a resolution of 100 micrometres using biomaterials, binding factors and cells that are pulled together in a device, extruded out of a syringe and cured with blue light or UV light. The system produce tissues that can replace the animals in tests currently performed in pharmaceutical and medical filed [38].

Therics Inc. is a Princeton-based biopharmaceutical company oriented to develop innovative products with a revolutionary $3 \mathrm{D}$ printing technology. With TheriForm micro-fabrication technology, the company is able to manufacture complex products that could not be produced by now-a-days conventional manufacturing technology. In 2008, Therics was taken over by Integra LifeSciences Holdings Corp [39].

Aprecia is a company that produces Spritam, the first FDA approved drug produced by 3D printing. Spritam uses ZipDose technology to assemble multiple layers of powder with an aqueous fluid, producing a porous, water-soluble structure that rapidly disintegrates if exposed to a liquid. This technology allowed the development of orodispersible formulations with high doses (up to $1,000 \mathrm{mg}$ ) of pharmacologically active substances [44].

Rainbow Biosciences is a division of Rainbow Coral Corp. that created the 3D BIO Assay, the first $3 \mathrm{D}$ bioprinting system for drug's toxicity screening. The system prints 3D structures made from biocompatible magnetic nanoparticles and cells [41].

\section{Personalized Pharmaceutical 3D printing}

It is predicted that 3D printing of drugs will have an endless impact on drug discovery and personalized therapy producing medicines with maximum efficacy and minimum toxicity [42]. It is generally accepted that $3 \mathrm{D}$ printing has three exclusive features in pharmaceutical field that improve the effect, safety and accessibility of drugs: it allows manufacturing of complex pharmaceutical products, personalization and on-demand production of medicines [43]. Last but not at least, 3D printing provides the solutions for fabrication of pharmaceutical products in various critical situations like natural disasters, military operations, in emergency and operating rooms and in healthcare units when time and resources are limited [44].
$3 \mathrm{D}$ printing technology provides an infinite number of opportunities for fabrication of patient-specific drug delivery devices and dosage forms for personalized drug therapy [45]. Currently, versatile therapeutic systems are developed with tailor-made formulas of different active pharmaceutical substances, in various doses and with various kinetic profiles. 3D printed pharmaceutical forms with particular designs and compositions offer the advantages of fabrication of multiple separate chambers that can be loaded with different substances, thus modulating the bioavailability of drugs [46].

\section{D printing of new pharmaceutical products}

The new era of medicine address the issues of safety and efficacy of drugs, requesting new methods for production and evaluation of pharmaceutical forms [48]. In the last years, 3D printing received a constant attention from pharmaceutical sector and important steps have been made promising prospective success of implementing new methods for design and production of high quality medicines by these state of the art technologies [48].

3D Pharming (the direct printing of pharmaceutical comprimates) represents a new innovative process for manufacturing controlled release drug delivery systems.

There are many examples of new pharmaceutical forms produced by $3 \mathrm{D}$ printing.

Verstraete et al used fused deposition modelling technology to manufacture thermoplastic polyurethane (TPU)-based personalized pharmaceutical forms loaded with high concentration of drugs (up to $60 \%$ $\mathrm{w} / \mathrm{w})$ [49].

Li et al used 3D printing for generation of gastrofloating tablets with a hydrophilic component made from hydroxypropyl methylcellulose. The extrusion molding agent was microcrystalline cellulose and the active compound was dipyridamole, a drug used to prevent blood clots formation after heart surgery, strokes and heart attacks [50].

Acosta-Vélez et al prepared a biocompatible photocurable polymeric ink for 3D printing of pharmaceutical products with hydrophilic drugs. The printing polymer was obtained from hyaluronic acid functionalized with norbornene moieties. This compound goes through a rapid polymerization process in the presence of Eosin Y as photoinitiator and poly(ethylene)glycol dithiol, if it is exposed to visible light. Ropinirole HCL was used as active compound for tablets formulation [51].

In 2015, FDA authorized the first 3D manufactured drug, Spritam $^{\circledR}$, that contains as active pharmacologic substance an anti-epileptic drug, levetiracetam $[52,53,54]$. Levetiracetam has 
FARMACIA, 2019, Vol. 67, 1

unique properties compared with other drugs with the similar pharmacologic activity [54, 55]. It can be used for treatment of partial onset seizures, myoclonic seizures in patients with juvenile myoclonic epilepsy and primary generalized tonicclonic seizures [56]. Spritam ${ }^{\circledR}$ is produced by an innovative technology (ZipDose technology) developed by Aprecia, a drug delivery platform company. ZipDose technology can be used to manufacture rapidly disintegrating orodispersible formulations of drugs by 3D printing [40].

ZipDose Technology prints a porous matrix made from multiple layers of powder fixed with an aqueous fluid that is further used to produce premeasured orodispersible formulations of drugs that disintegrate in the mouth with small quantities of liquids. Currently, is the only platform for formulation of pharmaceutical products that disintegrate rapidly and contain high quantities of active substances [40]. The advantages of ZipDose technology rely on the rapid disintegration of the tablets even at high dose of pharmaceutical compound (up to $1,000 \mathrm{mg}$ ), on the potential of using a large number of taste-masking excipients and on unit-doses delivery that increase patient compliance [57].

"Polypill" describe a pharmaceutical tablet that contains a mixture of several drugs. These comprimates have a great potential for cardiovascular therapy. Also, they could represent an inexpensive alternative to pharmaceutical forms used in current practice [58]. To date, conclusions about polypill's efficacy in cardiovascular diseases events and mortality are inaccessible and are investigated in clinical trials at present [59]. The CNIC-Ferrer polypill is the only product for which a marketing authorization has been granted in the EU, in other European countries and in Latin-America [60]. The Fuster-CNIC-Ferrer CV polypill (Trinomia ${ }^{\circledR}$, Sincronium $^{\circledR}$, Iltria ${ }^{\circledR}$ ) was developed in order to provide to patients accessibility to a simplified treatment, in an economical way. This polypill was designed, produced and patented by Ferrer. Active ingredients (atorvastatin, ramipiril and acetylsalicylic acid) are printed in a single capsule. Pharmacological substances properties remain unaffected and physico-chemical incompatibilities do not occur (between atorvastatin, ramipiril and acetylsalicylic acid there is a chemical incompatibility), 3D printing technologies allowing strict control of active ingredients location within the polypill and drug release kinetics [61].

Khaled et al used (3D) extrusion printing to obtain polypills for the treatment of cardiovascular diseases with five separate sections, each of them being loaded with a single drug. The polypill released the drugs according to two pharmacokinetic release profiles. The tablet contained an immediate release reservoir with aspirin and hydrochlorothiazide and three sustained release compartments with pravastatin, atenolol and ramipril [62]. The same author also obtained by 3D extrusion printing a polypill containing a guaifenesin bilayer tablet, that matches the international standards stated in the US Pharmacopeia [63].

\section{Development of new medical devices}

Cannabinoids are involved in analgesia and in antiinflammatory processes and can be used to treat various conditions like chronic pain $[64,65]$. The major components of cannabis are $\Delta 9$ tetrahydrocannabinol with psychotropic action and cannabidiol, a non-psychotropic component, with anti-inflammatory effects $[66,67,68]$.

The Syqe Inhaler ${ }^{\mathbb{R}}$ was developed by Syqe Medical, a start-up company from Tel Aviv. Is the first-inclass pocket-sized selective-dose cannabis inhaler that have been made with $3 \mathrm{D}$ printing technology ( $80 \%$ of The Syqe inhaler was 3D printed using Stratasys MED610 biocompatible material with Stratasys Objet 350 3D Printer). The device can be connected to a Wi-Fi network on a smart phone or tablet. pSyqe Inhaler Exo ${ }^{\circledR}$ is the inhaler's variant that can be used in hospital units [69]. The devices maintain an excellent ratio between pharmacological action and psychoactivity. Eisenberg et al studied the pharmacokinetics, safety, tolerability and efficacy of Syqe Inhaler ${ }^{\circledR}$ device in a trial program and proved the efficacy of this $3 \mathrm{D}$ printed instrument according to the required pharmaceutical standards $[69,70]$.

We can also mention non printed pharmaceutical products that contains cannabinoids, like those ones obtained by $4 \mathrm{GW}$ Pharmaceuticals, a leader company that design and develops pharmaceutical forms with cannabinoids for the treatment of rare types of epilepsy syndromes [71, 72]. Some of these products have already been tested in studies FDA approved. Epidiolex ${ }^{\circledR}$ is an oral solution with cannabidiol (CBD) extracted from plants. The company received the FDA authorization for a clinical trials program [72]. Sativex ${ }^{\circledR}$ (US approved name: nabiximols) is an oromucosal spray of a formulated extract of the Cannabis sativa plant that contains the principal cannabinoids delta-9tetrahydrocannabinol (THC) and CBD in a $1: 1$ ratio, and specific minor cannabinoids and other non-cannabinoid components. Sativex ${ }^{\circledR}$ has been approved in 30 countries so far (outside the United States) [72]. In Germany, Sativex ${ }^{\circledR}$ administration was approved in 2011. THC-containing capsules and oil are not approved yet in this country (German Narcotic Drugs Act) [73]. 
Cannabinoids approved by the U.S. Food and Drug Administration (FDA) for clinical use [74, 75]

\begin{tabular}{|c|c|c|c|c|}
\hline Cannabinoid & Active substances & Formulation & Company & Indications \\
\hline Cesamet $^{(\mathbb{R}}$ & $\begin{array}{c}\text { Nabilone a } \\
\text { dimethylheptyl } \\
\text { analog of THC }\end{array}$ & $\begin{array}{c}\text { Capsules for } \\
\text { oral } \\
\text { administration }\end{array}$ & $\begin{array}{c}\text { Meda } \\
\text { Pharmaceuticals, } \\
\text { Somerset, NJ, USA }\end{array}$ & $\begin{array}{l}\text { Severe nausea and vomiting } \\
\text { associated with chemotherapy } \\
\text { neuropathic pain and pain } \\
\text { associated with cancer and } \\
\text { fibromyalgia }\end{array}$ \\
\hline Marinol $^{\circledR}$ & Dronabinol THC & $\begin{array}{c}\text { Capsules for } \\
\text { oral } \\
\text { administration }\end{array}$ & $\begin{array}{l}\text { AbbVie, Inc., North } \\
\text { Chicago, IL, USA }\end{array}$ & $\begin{array}{l}\text { Nausea and vomiting in } \\
\text { patients receiving cancer } \\
\text { chemotherapy who failed to } \\
\text { respond to conventional } \\
\text { antiemetics } \\
\text { appetite stimulant for patients } \\
\text { with wasting diseases such as } \\
\text { cancer and HIV/AIDS } \\
\end{array}$ \\
\hline Sativex $^{\circledR}$ & $\begin{array}{c}\text { Cannabis extract } \\
\text { 50:50 THC and CBD }\end{array}$ & $\begin{array}{l}\text { oromucosal } \\
\text { spray }\end{array}$ & $\begin{array}{c}\text { GW Pharmaceuticals, } \\
\text { Cambridge, United } \\
\text { Kingdom }\end{array}$ & $\begin{array}{l}\text { Treatment of chronic pain that } \\
\text { is unresponsive to opioids }\end{array}$ \\
\hline
\end{tabular}

\section{D printing of pharmacologically active substances}

$3 \mathrm{D}$ printers can be transformed in successful automated minilabs for chemical synthesis of pharmaceutical compounds, as Professor Cronin and his collaborators from the University of Glasgow have been already proved. They produced a nonsteroidal anti-inflammatory drug, ibuprofen, by a three-step process, using a modified open source 3D printing platform, RepRap. Professor Cronin has provided, at the same time, a low-cost solution for $3 \mathrm{D}$ printing of pharmacologically active substances. The cost associated with the $3 \mathrm{D}$ printer used in this study was about 600-700 $€$ [76].

\section{Legal issues concerning 3D printing of drugs and medical devices}

FDA is reviewing $3 \mathrm{D}$ printed products and evaluated the safety and efficacy of $3 \mathrm{D}$ printed medical devices and 3D printed drugs [77]. Two laboratories in the FDA's Office of Science and Engineering Laboratories, Functional Performance and Device Use Laboratory and Laboratory for Solid Mechanics, are investigating the future of 3D printing in healthcare field [77].

In 2016, the FDA distributed a guide book with Technical Considerations for Additive Manufactured Devices that contains recommendations for developers who produce equipment through 3D printing techniques [77].

\section{Conclusions}

Currently, applications of 3D printing innovative technologies are the most powerful and promising tools in the pharmaceutical field. Even there are numerous difficulties regarding technical resources, safety and security concerns and lack of a legal base, the scientists and physicians already foreknow the great opportunities are raising from 3D printing technology applications in healthcare. The pharmaceutical world will be inevitable changed in the next future by 3D printed medicines, opening new directions for personalization of drug therapy or development of new pharmaceutical forms and solving important problems that occur daily in drug therapy. The 3D printed market will forcefully expand as a result of innovative healthcare solutions, improving the life quality for a large number of patients.

\section{References}

1. Park J-Y, Kim H-Y, Kim J-H, Kim J-H, Kim W-C, Comparison of prosthetic models produced by traditional and additive manufacturing methods. The Journal of Advanced Prosthodontics, 2015; 7(4): 294302.

2. Lal H, Patralekh MK, 3D printing and its applications in orthopaedic trauma: A technological marvel. J Clin Orthop Trauma, 2018; 9(3) :260-268.

3. Yi H-G, Lee H, Cho D-W, 3D printing of Organs-OnChips. Bioengineering (Basel), 2017; 4(1): 1-22.

4. Zadpoor AA, Design for additive bio-manufacturing: from patient-specific medical devices to rationally designed meta-biomaterials. Int $J$ Mol Sci., 2017;18(8): 1-18.

5. Torabi K, Farjood E, Hamedani S, Rapid prototyping technologies and their applications in prosthodontics, a review of literature. Journal of Dentistry, 2015; 16(1): $1-9$.

6. Ligon SC, Liska R, Stampfl J, Gurr M, Mülhaupt R, Polymers for $3 \mathrm{D}$ printing and customized additive manufacturing. Chemical Reviews, 2017; 117(15): 10212-10290.

7. Lee J, Kim H-C, Choi J-W, Lee IH, A review on 3D printed smart devices for $4 \mathrm{D}$ printing. International Journalof Precision Engineeringand ManufacturingGreen Tecnhology, 2017; 4(3): 373-383.

8. Konta AA, García-Piña M, Serrano DR, Personalised 3D printed medicines: which techniques and polymers 
FARMACIA, 2019, Vol. 67, 1

are more successful? Bioengineering, 2017; 4(4): 116.

9. Alamán J, Alicante R, Peña JI, Sánchez-Somolinos C, Inkjet printing of functional materials for optical and photonic applications. Materials, 2016; 9(11): 1-47.

10. Jang J, 3D bioprinting and in vitro cardiovascular tissue modeling. Bioengineering, 2017; 4(3): 1-20.

11. www.stratasys.com.

12. Tartarisco G, Gallonea G, Carpia F, Vozzia G, Polyurethane unimorph bender microfabricated with Pressure Assisted Microsyringe (PAM) for biomedical applications. Materials Science and Engineering $C$, 2009; 29(6): 1834-1841.

13. Dias AD, Kingsley DM, Corr DT, Recent advances in bioprinting and applications for biosensing. Biosensors, 2014; 4(2): 111-136.

14. Wang X, Ao Q, Tian X, Fan J, Wei Y, Hou W, Tong $\mathrm{H}$, Bai S, 3D bioprinting technologies for hard tissue and organ engineering. Materials, 2016; 9(10): 1-23.

15. Harkness WA, Goldschmid JH, Free-form spatial 3-D. Patent Application Publication, 2016; US 2016/0031156A1.

16. https://phys.org.

17. www.osirix-viewer.com.

18. www.slicer.org.

19. http://meshmixer.com.

20. www.mimic3d.com.

21. www.3dprinterworld.com.

22. http://aspectbiosystems.com.

23. http://bioprinting.aether1.com.

24. www.regenhu.com.

25. https://formlabs.com/3d-printers/form-2.

26. https://envisiontec.com/3d-printers/3d-bioplotter.

27. https://3dprintingindustry.com.

28. https://www.biotronik.com/en-gb.

29. https://www.stryker.com.

30. https://www.drugwatch.com.

31. https://3dprint.com.

32. http://www.biomet.com.

33. http://bio.broadcastmed.net.

34. http://www.orthopaediclist.com.

35. http://www.smith-nephew.com.

36. www.syncera.com.

37. www.medgadget.com.

38. https://newatlas.com.

39. www.pharmaceuticalonline.com.

40. https://aprecia.com.

41. www.rainbowbiosciences.com/

42. Kurzrock R, Stewart DJ, Click chemistry, 3D-printing, and omics: the future of drug development. Oncotarget., 2016; 7(3): 2155-2158.

43. Norman J, Madurawe RD, Moore CM, Khan MA, Khairuzzaman A, A new chapter in pharmaceutical manufacturing: 3D-printed drug products. Adv Drug Deliv Rev., 2017; 108: 39-50.

44. Vijayavenkataraman S, Fuh JYH, Lu WF, 3D printing and $3 \mathrm{D}$ bioprinting in pediatrics. Bioengineering, 2017; 4(3): 1-11.

45. Maroni A, Melocchi A, Parietti F, Foppoli A, Zema L, Gazzaniga A, 3D printed multi-compartment capsular devices for two-pulse oral drug delivery. $J$ Control Release, 2017; 268: 10-18.

46. Palo M, Holländer J, Suominen J, Yliruusi J, Sandler $\mathrm{N}, 3 \mathrm{D}$ printed drug delivery devices: perspectives and technical challenges. Expert Rev Med Devices, 2017; 14(9): 685-696.

47. Șaramet G, Rădulescu FȘ, Miron DS, Bărbuceanu ȘF, Stănescu AA, Vlaia L, Pițuru S, Lupuliasa D, Study describing the formulation and the release of some active pharmaceutical ingredients from HPMC hydrophilic matrix tablets. Note I. Farmacia, 2017; 65(5): 690-697.

48. Dumitrescu I-B, Lupuliasa D, Drăgoi CM, Nicolae AC, Pop A, Şaramet G, Drăgănescu D, The age of pharmaceutical 3D printing. Technological and therapeutical implications of additive manufacturing. Farmacia, 2018; 66(3): 366-389.

49. Verstraete G, Samaro A, Grymonpré W, Vanhoorne V, Van Snick B, Boone MN, Hellemans T, Van Hoorebeke L, Remon JP, Vervaet C, 3D printing of high drug loaded dosage forms using thermoplastic polyurethanes. Int J Pharm., 2017; 536(1): 318-325.

50. Li Q, Guan X, Cui M, Zhu Z, Chen K, Wen H, Jia D, Hou J, Xu W, Yang X, Pan W, Preparation and investigation of novel gastro-floating tablets with 3D extrusion-based printing. Int J Pharm., 2017; 535(12): 325-332.

51. Acosta-Vélez GF, Linsley CS, Craig MC, Wu BM, Photocurable bioink for the inkjet 3D pharming of hydrophilic drugs. Bioengineering, 2017; 4(1): 1-11.

52. Nowack A, Malarkey EB, Yao J, Bleckert A, Hill J, Bajjalieh SM, Levetiracetam reverses synaptic deficits produced by overexpression of SV2A. PLOS ONE, 2011; 6(12): 1-8.

53. Deshpande LS, DeLorenzo RJ, Mechanisms of levetiracetam in the control of status epilepticus and epilepsy. Frontiers in Neurology, 2014; 5: 1-5.

54. Lee C-Y, Chen C-C, Liou H-H., Levetiracetam inhibits glutamate transmission through presynaptic $\mathrm{P} / \mathrm{Q}$-type calcium channels on the granule cells of the dentate gyrus. British Journal of Pharmacology, 2009; 158(7): 1753-1762.

55. Weijenberg A, Brouwer OF, Callenbach PMC, Levetiracetam monotherapy in children with epilepsy: A systematic review. CNS Drugs, 2015; 29(5): 371382.

56. *** New Drugs/Drug News/New Medical Devices. $P$ T., 2015; 40(9): 552, 554-560, 582-583.

57. www.spritam.com.

58. Jowett S, Barton P, Roalfe A, Fletcher K, Hobbs FDR, McManus RJ, Mant J, Cost-effectiveness analysis of use of a polypill versus usual care or best practice for primary prevention in people at high risk of cardiovascular disease. PLoS ONE, 2017; 12(9): 1-15.

59. Roy A, Naik N, Srinath Reddy K, Strengths and limitations of using the polypill in cardiovascular prevention. Current Cardiology Reports, 2017; 19(5): 1-8.

60. Fuster V, Gambús F, Patriciello A, Hamrin M, Grobbee DE, The polypill approach - An innovative strategy to improve cardiovascular health in Europe. BMC Pharmacology \& Toxicology, 2017; 18: 1-8.

61. Tamarago J, Castellano JM, Fuster V., The FusterCNIC-Ferrer Cardiovascular Polypill: a polypill for secondary cardiovascular prevention. International Journal of Cardiology, 2015; 201(S1): S15-S22.

62. Khaled SA, Burley JC, Alexander MR, Yang J, Roberts CJ, 3D printing of five-in-one dose 
combination polypill with defined immediate and sustained release profiles. Journal of Controlled Release, 2015; 217(10): 308-314.

63. Khaled SA, Burley JC, Alexander MR, Roberts CJ, Desktop 3D printing of controlled release pharmaceutical bilayer tablets. Int J Pharm., 2014; 461(1-2): 105-111.

64. Kim PS, Fishman MA, Cannabis for pain and headaches: Primer. Curr Pain Headache Rep., 2017; 21(4): 1-11.

65. Miller RJ, Miller RE, Is cannabis an effective treatment for joint pain? Clin Exp Rheumatol., 2017; 35 Suppl 107(5): 59-67.

66. McPartland JM, Duncan M, Di Marzo V, Pertwee RG, Are cannabidiol and $\Delta 9$-tetrahydrocannabivarin negative modulators of the endocannabinoid system? A systematic review. British Journal of Pharmacology, 2015; 172(3): 737-753.

67. Wang Y, Mukhopadhyay P, Cao Z, Wang H, Feng D, Haskó G, Mechoulam R, Gao B, Pacher P, Cannabidiol attenuates alcohol-induced liver steatosis, metabolic dysregulation, inflammation and neutrophilmediated injury. Scientific Reports, 2017; 7: 1-12.

68. Iffland K, Grotenhermen F, An update on safety and side effects of cannabidiol: A review of clinical data and relevant animal studies. Cannabis and Cannabinoid Research, 2017; 2(1): 139-154.
69. www.syqemedical.com.

70. Eisenberg E, Ogintz M, Almog S, The pharmacokinetics, efficacy, safety, and ease of use of a novel portable metered-dose cannabis inhaler in patients with chronic neuropathic pain: a phase 1a study. J Pain Palliat Care Pharmacother., 2014; 28(3): 216-225

71. Neubauer D, Perković Benedik M, Osredkar D, Cannabidiol for treatment of refractory childhood epilepsies: Experience from a single tertiary epilepsy center in Slovenia. Epilepsy Behav., 2018; 81: 79-85.

72. www.gwpharm.com/

73. Häuser W, Fitzcharles M-A, Radbruch L, Petzke F, Cannabinoids in pain management and palliative medicine: An overview of systematic reviews and prospective observational studies. Deutsches Ärzteblatt International, 2017; 114(38): 627-634.

74. Zurier RB, Burstein SH, Cannabinoids, inflammation, and fibrosis., FASEB J., 2016; 30(11): 3682-3689.

75. Chwistek M, Recent advances in understanding and managing cancer pain. F1000Research, 2017;6: 1-10.

76. Kitson PJ, Glatzel S, Cronin L, The digital code driven autonomous synthesis of ibuprofen automated in a 3Dprinter-based robot. Beilstein J Org Chem., 2016; 12: 2776-2783

77. https://www.fda.gov. 